\title{
Aktivitas Tabir Surya Formula Bedak Dingin Jawa
}

\author{
Diah Puti Kusumanti ${ }^{1}$, Nutrisia Aquariushinta Sayuti ${ }^{1}$, Indarto AS ${ }^{1}$ \\ 1)Indonesian Traditional Herbals Department, Health Polytechnic of Surakarta \\ Jl. Kesatriyan 2, Danguran, Klaten Selatan, Klaten, Indonesia 57127 \\ Email : nutrisayuti@gmail.com
}

\begin{abstract}
Abstrak
Sinar matahari mengandung sinar ultraviolet yang mengakibatkan efek negatif pada kulit sehingga sediaan tabir surya dibutuhkan untuk melindungi kulit. Bedak dingin Jawa merupakan salah satu sediaan tabir surya yang telah digunakan secara empiris untuk melindungi kulit dari paparan sinar matahari. Formula bedak dingin Jawa tediri dari tepung beras (Oryza sativa L.), pati bengkoang (Pachyrhizu serorus (L.) $\mathrm{Urb}$ ), kulit kayu manis jangan (Cinnamomum burmanii (nees) BI), pulasari (Alyxia reinwardtii $\mathrm{BI}$ ), temugiring (Curcuma heyneana) dan biji pinang (Areca catechu L.). Penelitian ini bertujuan untuk mengetahui aktivitas tabir surya kombinasi tepung beras dan ekstrak sonikasi simplisia lain dalam formula bedak dingin jawa melalui pengujian nilai Sun Protection Factor (SPF), nilai persen transmisi eritema (\%Te) dan pigmentasi $(\% \mathrm{Tp})$. Simplisia penyusun bedak dingin dibuat ekstrak dengan metode sonikasi dan dikombinasikan dengan tepung beras di dalam larutan dengan perbandingan 1:1 kemudian dilakukan pengujian aktivitas tabir surya dengan menggunakan spektrofotometri UV-Vis. Hasil penelitian ini adalah aktivitas tabir surya formula bedak dingin memiliki nilai SPF 15,6 dinyatakan dalam kategori proteksi maximal, nilai persen transmisi eritema 1,2 dinyatakan dalam kategori proteksi ultra, dan nilai persen transmisi pigmentasi 9,3 dalam kategori sunblock. Suatu sediaan tabir surya dinyatakan efektif dalam melindungi kulit bila memiliki nilai SPF yang tinggi, sedangkan nilai \%Te dan \%Tp efektif melindungi kulit bila nilainya rendah. Melalui penelitian ini dapat disimpulkan bahwa formula bedak dingin jawa efektif dalam melindungi kulit dari paparan sinar matahari.
\end{abstract}

Kata Kunci : Aktivitas Tabir Surya, Bedak Dingin Jawa, SPF, Transmisi Eritema, Pigmentasi

\begin{abstract}
Sunlight contains ultraviolet rays that have a negative effect on the skin so that the sunscreen dosage form is needed to protect the skin. The Javanese cold mask is one of thesunscreen dosage forms which has been used empirically to protect the skin from sun exposure. The formula of Javanese cold mask consists of rice flour (Oryza sativa L.), yam bean starch (Pachyrhizus erorus (L.) Urb), cinnamon bark cortex (Cinnamomum burmanii (nees) BI), pulasari (Alyxia reinwardtii $\mathrm{BI}$ ), temugiring (Curcuma heyneana) and areca nut (Areca catech $u$ L.). This study aimed to determine the sunscreen activity of the combination of rice flour and sonication extract of the other crude drugsin the formula ofJavanese cold mask through testing the Sun Protection Factor value (SPF), the percentage of erythema transmission $(\% \mathrm{Te})$ and percentage of pigmentation $(\% \mathrm{Tp})$. The extract was made by the sonication method and combined with rice flour in a solution at a ratio of $1: 1$ then tested the sunscreen activities by UV-Vis spectrophotometry method. The result showed that the sunscreen activity of the Javanese cold mask formula hadan SPF value of 15.6, expressed in maximal protection category, the value of \% $\%$ of 1.2 expressed in ultra protection category, and the value of \% $\mathrm{Tp}$ of 9.3 in the category of sunblock. A sunscreen dosage form could be effective to protect the skin when it has a high SPF value, while the value of $\% \mathrm{Te}$ and $\% \mathrm{Tp}$ is effective to protect the skin when its value is low. It was concluded that the formula of Javanese cold mask was effective to protect the skin from sun exposure.
\end{abstract}

Keywords : Sunscreen Activity, Javanese Cold Mask, SPF, Erythema Transmission, Pigmentation 


\section{Introduction}

Traditional herb had been used for generations to maintain the health of a woman's skin. The use of traditional herbs was still preserved by Javanese women of of the palace environment in the form of ratus, mask, cream, cold mask, and so forth. The habits of Javanese women in his life to protect the body from sun exposure by using Javanese cold mask that the concoction was a mixture of rice flour and some crude drugs herbal plants consisting of yam bean (Pachyrhizu serosus (L.) Urb), cinnamon bark (Cinnamomum burmanii ( nees) BI), pulasari (Alyxia reinwardtii $\mathrm{Bl}$ ), temugiring (Curcuma heyneana) and betel nut (Areca catech $u$ L.). This fact concluded that the cold powder components contain substances that could protect the skin from sun exposure (sunscreen), so as to reduce the impact of exposure to ultraviolet rays even though no one had studied it.

Sunlight were a vital life source that can provide beneficial and adverse effects for human life. Ultraviolet rays contained in sunlight is very harmful to the skin because it had high energy and carcinogenic. UV $B$ rays were the most harmful ultraviolet rays that had power 1000-fold compared to UV A and C. Thus the protection needed to minimize the ill effects of exposure to ultraviolet rays on the skin in the form of sunscreen to avoid the effects of excessive sun exposure on the skin, can be used sunscreen. ${ }^{[1]}$

Sunscreen were dossage form which used to avoid the negative effects of UV rays on the skin in the form of structural damage to the skin and decreased function of the skin on the human body as a result of the solar radiation process. Sunscreens were necessary to prevent photoaging. To determine the sunscreens effectiveness of the dossage form can be seen from the Sun Protection Factor (SPF), the percentage of erythema transmission (\%Te) and percentage of pigmentation ( $\% \mathrm{Tp})$. SPF was the amount of ultraviolet (UV) energy required to achieve Minimal Erythema Dose
(MED) on sunscreen protected skin divided by the amount of UV light energy required to reach MED on unprotected skin. There were many a widespread assumption that the SPF value affects the skin protection intensity from the sun but it wasn't definitely be $100 \%$ in protecting the skin. SPF had a range of between 2-60. Dermatologists recommend that the use of sunscreen to the skin that have SPF values between 15-30. ${ }^{[2]}$ Erythema was an acute inflammation of the skin associated with redness arising because of UV radiation. ${ }^{[3]}$ Pigmentation was a brown color reaction onset (tanning) and the formation of new melanin. ${ }^{[4]}$ These facts made researchers interested in studying the activity of sunscreen from the cold powder formula Java in vitro by determining the SPF value, the value of the percentage of transmission erythema $(\% \mathrm{Te})$ and the percentage of transmission pigmentation (\% Tp).

\section{Method}

Materials and tools

Rice fluor and crude drug that consist of rice flour, yam bean starch, cinnamon bark cortex, pulasari, temugiring and areca nut (Areca catechu L.). The crude drugs were obtained from the Pasar Gede, Solo, Central Java, and chemicals: ethanol $70 \%$, acetic acid with a pharmacy degree that obtained from PT. Bratachem and sulfuric acid from Aldrich

The tools were iron mill, sieve mesh 60 , vacuum rotary evaporator (Ika), waterbath, mortar, analytical balance (Ohaus), Beaker glass (Pyrex), ultrasonification (Branson), UV-Vis Spectrophotometer (Optizen), Climatic chamber (memert), Pipette volume of $5 \mathrm{ml}$ (Pyrex), 4 sets of flask sizes $20 \mathrm{ml}$, $25 \mathrm{ml}, 50 \mathrm{ml}$ and $100 \mathrm{ml}$ (Pyrex), test tubes, aluminum foil.

Preparation of the ultrasonification extract

The crude drugs that consist of yam bean starch, cinnamon bark cortex, pulasari, temugiring and areca nut were ground and then sieved with mesh 60. Moisture 
content analysis of the powder was done by a dry oven method. Each of the powder was weighed 500 grams and divided into 10 parts. Each part was dissolved with 250 $\mathrm{ml}$ ethanol $70 \%$ in beakerglass sized 500 $\mathrm{ml}$ then its been closed with aluminium foil and the mixture was extracted using ultrasonic waves at a frequency of $50 \mathrm{KHz}$ for 15 minutes at $50^{\circ} \mathrm{C}$. To extract that is not easily dissolved, then the sonication process is repeated to obtain a clear extract. Then filtered, the dregs was soaked for a day to perfect the withdrawal of the extraction. The extracts were evaporated at vacuum evaporator and water bath. Extract yield was calculated with the equation :

Yield $=$ weight of concentrated extract $\times 100 \%$ weight of simplicia powder

The concentrates extracts were conducted alcohol-free test with esterification reaction. It was conducted with reaction of 0.1 gram Extract, acetic acid and concentrated sulfuric acid. The five extracts were mixed with the same concentration for each extract. The mixed extract was called the ultrasonic extract.

Activation of kojic acid in rice flour

Rice soaked for three days with replacement of water every day to enable kojic acid contained in rice flour, and rice is dried and milled and sieved to 60 mesh sieve.

Preparations of the formula cold Javanese mask.

Javanese cold mask Formula was made by mixing rice flour and ultrasonifikation extract in the same concentration ratio to form a paste and then the paste shaped as small ball, placed in a tray regularly and cover with black cloth, then dried in the sun.

\section{Determination of SPF Value}

The solution of cold mask of $1000 \mathrm{ppm}$ were made by weighing $100 \mathrm{mg}$ of cold mask, crushed with the help of mortar and stamfer then dissolved in $100 \mathrm{ml}$ of $70 \%$ ethanol, if there was a part that wasn't soluble, It can be heated at temperature of $50^{\circ} \mathrm{C}$, for 30 minutes until obtained a clear solution. The solution absorbance was measured by using UV-Vis spectrophotometry at a wavelength of 290-320 nm using 70\% ethanol as a blank. Absorption value recorded at intervals of 5 $\mathrm{nm}$. Then its SPF value determined by the formula:

$$
\mathrm{SPF}=\mathrm{CF} \times \sum^{320} E E(\lambda) \times \mathrm{I}(\lambda) \times \operatorname{Abs}(\lambda)
$$

where $\mathrm{CF}=$ corregction factor $(10), \mathrm{EE}(\lambda)$ $=$ erythmogenic effect of radiation with wavelength $\lambda, \operatorname{Abs}(\lambda)=$ spectrophotometric absorbance values at wavelength $\lambda$.

After a cold powder SPF values was obtained then set sunscreen activity categories according to Sayre et al (1979) and the American Food and Drug Administration (FDA) on Charisma L (2012) as listed in Table $1[5,6]$

Determination of $\% \mathrm{Te}$

The solution's absorbance was measured by using UV-Vis spectrophotometre in the wavelength range 292.5 to $317.5 \mathrm{~nm}$ using $70 \%$ ethanol as a blank. Absorption value recorded at intervals of $5 \mathrm{~nm}$.

$\% \mathrm{Te}$ value was calculated by the formula:

$$
\begin{gathered}
\% \mathrm{Te}=\sum(T x F e) \\
\sum F e
\end{gathered}
$$

Determination of $\% \mathrm{Tp}$

The absorption of Cold mask solution was measured by using UV-Vis spectrophotometry in the wavelength range from 322.5 to $375.5 \mathrm{~nm}$ by using $70 \%$ ethanol as a blank. Absorption value recorded at intervals of $5 \mathrm{~nm}$. Value $\% \mathrm{Tp}$ is calculated using the formula:

$$
\begin{gathered}
\% \mathrm{Tp}= \\
\sum(T x F p) \\
\sum F p
\end{gathered}
$$

$\% \mathrm{Te}$ and $\% \mathrm{Tp}$ of cold mask solution defined sunscreen activity categories in accordance with the dikemukaan by Sayre et al (1979) and American Food and Drug Administration (FDA) on Charisma L (2012) as listed in Table $2^{[5,6]}$ 
Table 1. SPF value category according to the Food and Drug Administration (FDA)

\begin{tabular}{cc}
\hline Type of Protection & SPF Value \\
\hline Minimal & $1-4$ \\
Moderate & $4-6$ \\
Extra & $6-8$ \\
Maximal & $8-15$ \\
Ultra & $>15$ \\
\hline
\end{tabular}

Data analysis technique

Descriptive analysis of the data presented in narrative form and figure.

\section{Result}

The moisture content of the powder of rice flour, yam bean starch, cinnamon bark cortex, pulasari, temugiring and areca nutrespectively $5.51 \% \mathrm{w} / \mathrm{w}, 6.65 \% \mathrm{w} / \mathrm{w}$, $1.67 \% \mathrm{w} / \mathrm{w}, 8.06 \% \mathrm{w} / \mathrm{w}, 6.19 \% \mathrm{w} / \mathrm{w}$ and $7,8 \%$. This study uses rice (Oryza sativa) with active kojic acid prepared by the process of soaking the rice for at least 24 hours [8]. Yam bean extraction yield was $15,2 \%$, the yield of temugiring extraction was $4,9 \%$, the pulasari extraction yield of $7,1 \%$, the areca nut extraction yield of $13,0 \%$ and cinnamon bark extraction amounted to $12,8 \%$. The esterification test showed that the extracts had been free of the solvent.

Sunscreen activity analysis of Javanesse Cold Mask was done by determine the SPF value, $\% \mathrm{Te}, \% \mathrm{Tp}$ and determination of the protection category. The results of the activity of cold powder sunscreen Java are listed in Table 3.

Sunscreen activity test of cold mask had done 3 times to get a more accurate result. The test results stated that the cold mask had an SPF value of 15.5 which otherwise
Table 2. Category Rating Sunscreen

\begin{tabular}{ccl}
\hline \%Te & $\mathbf{\% T p}$ & $\begin{array}{c}\text { Category Rating } \\
\text { Sunscreen }\end{array}$ \\
\hline$<1$ & $3-40$ & Sunblock \\
$1-6$ & $42-86$ & Ultra Protection \\
$6-12$ & $45-86$ & Suntan \\
$10-18$ & $45-86$ & Fast tanning \\
\hline
\end{tabular}

had the maximal potential to protect the skin in accordance with that proposed by the American Food and Drug Administration (FDA) on Charisma L's research (2012).

\section{Discussion}

It showed that moisture levels for the crude drugs less than $10.00 \%$. Moisture content for crude drugs is good if it isn't more than $10.00 \%$. It would lead to a process by enzymatic and microbial damage if the moisture content is greater than $10.00 \%$. The chemistry will be changed by enzym into other products that may no longer have pharmacological effects such as compounds of origin. It wouldn't happen if the crude drugs has been dried to have a low moisture content ${ }^{[7]}$. It could be said that the powder met the requirements of the moisture content.

The extraction used ultrasonification methods. The study conducted by Cameron and Wang in 2006, stated that the method was more efficient in time with the same results as using other methods ${ }^{[9]}$. In a study conductedbyPrasiddhaIJ, etal in 2016 , stated that the sonication process was intended to remove phenolic compounds, especially flavonoids ${ }^{[10]}$. Phenolic compounds had a bond related to benzene core, It was the result when exposed to sunlight in

Table 3. Determination of Sunscreen Activities Javanese Cold Mask

\begin{tabular}{ccl}
\hline Parameter & Value & \multicolumn{1}{c}{ Protection Category } \\
\hline SPF & $15,6 \pm 0,4$ & Maximum protection \\
$\% \mathrm{Te}$ & $1,2 \pm 0,5$ & Ultra Protection \\
$\% \mathrm{Tp}$ & $9,3 \pm 0,8$ & Sunblock \\
\hline
\end{tabular}


the form of UV resonance would occur by transferring electrons, this compound can also be used as a photoprotective, as quersetin, alkaloids, phenols simple as acid p- kumarik, saponins, tannins, anthocyanins, and protokatekin. Flavonoids had the ability as a sunscreen because of the chromophore group. The chromophore group was an aromatic system that had the ability to absorb UV light. Flavonoids had a performance in counteracted free radicals and bind ions thereby minimizing the exposure to UV rays on the skin ${ }^{[11]}$.

The esterification test showed that the extracts had been free of the solvent. It was shown no formation of ester typical odor of ethanol. The test purposed to identify alcohol-free contained in the extract.

The test results stated that the cold mask had an SPF value of 15.5 which otherwise had the maximal potential to protect the skin in accordance with that proposed by the American Food and Drug Administration (FDA) on Charisma L (2012).

The determination of $\% \mathrm{Te}$ showed an average value of 1.2 was expressed into ultra protection value while the determination of $\% \mathrm{Tp}$ indicated the average value of 9.3 expressed as protection Sunblock. SPF value, $\% \mathrm{Te}$ and $\mathrm{Tp} \%$ represent the sunscreen activity of cold mask against UV exposure, but the study hadn't done the process of identifying the content of compounds. The effectiveness of a sunscreen form can be indicated by the SPF value, which is defined as the amount of UV energy that required to achieve minimal erythema dose (MED) on skin that protected by the sunscreen form, divided by the amount of UV energy that required to reach MED on the skin that wasn't given protection. MED is defined as the time period or the lowest dose of UV radiation required to cause erythema [12] The study suggested that the cold mask that had been made effective as a good protection against the harmful effects of sunlight by reflecting and scatter UV radiation can adversely affect the skin. it was the same as that expressed by Sugihartini, N on research in 2011 which stated that rice flour in cold mask serves to reflect and scatter sunlight [13]. The statement proposed by Agustin et al in 2013 in their observations stated that the determination of SPF value and \%Te used to show protection against UV-B rays, whereas \% Tp was used to show protection against UV-A rays. Sunscreen above was effective in protecting the skin is well demonstrated by the protection category in which the SPF value was higher, the same as expressed by Agustin R et al in a study in 2013 which stated that sunscreen was effective in protecting the skin from sun exposure when it had a higher value (more than 2), while the value of $\% \mathrm{Te}$ and $\% \mathrm{Tp}$ had good protection shown by category of hedge $\%$ Te and $\%$ Tp lower [14]. It was the same as expressed by Sugihartini, in 2011 where the research shows that the value of $\% \mathrm{Te}$ and $\mathrm{Tp}$ have good protection if the value is smaller ${ }^{[13]}$.

The mechanism of protection against skin sunscreen were as follows: sunscreen chemical molecules that absorb energy from UV rays was then subjected to excitation from the ground state to the level of higher energy. When excited molecules return to a lower position, there would be the energy release process. The UV rays of higher energy after being absorbed by the chemical sunscreens will have lower energy, so it can reduce the negative impact of UV exposure [14].

This possibility was the high amount of polyphenols that effect on the sunscreen activity. Phenolic compounds that contained on extract had a mutually conjugated bond in the benzene nucleus when exposed to UV light resonance will occur by way of electronic transfer. The existence of a common conjugation system in phenolic compounds and chemicals that are usually contained in the sunscreens form cause of this compound has potential as photoprotective. Flavonoids were the largest group of phenolic compounds. Flavonoids also had potential as sunscreen because of the chromophore groups that generally gave 
a yellow color in plants. The chromophore group were a conjugated aromatic system which caused a strong ability to absorb light in the wavelength range of UV rays on both UVA and UVB ${ }^{[15]}$.

\section{Conclusion}

Javenese cold mask effectively used as a sunscreen indicated by the SPF value in the category of maximum protection, $\% \mathrm{Te}$ in the category of ultra protection and \% $\mathrm{Tp}$ are included in the category of sunblock protection.

\section{Acknowledgments}

The authors were highly thankful to the Jamu Laboratories of Health Polytechnic Surakarta for providing all the facilities for the research work.

Conflict of Interest: We declare that we have no conflict of interest.

\section{Refference}

[1] Kaur, C. D dan S. Saraf. In Vitro Sub Protection Factor Determination of Herbal Oils Used in Cosmetics. Pharmacognosy Research. 2009; 2:22-23

[2] Romanowski, S. What Does "SPF" Really Mean? 2012. http://www.self. com/flash /beauty-blog/2012/ whatdoes-spf-really-mean accessed on 10 Oktober 2016

[3] Rigel DS, Weiss RA, Lim HW, Dover JS. Photoaging. 2004. New York: Marcel Dekker Inc

[4] Fisher GJ, Kang S., Varani J, BataCsorgo Z, Wan Y, Datta S, Voorhees JJ. Mechanisms of photoaging and chronological skin aging. Search Dermatology. 2012; Vol. 138:146270

[5] Sayre, RM., et-al. Comparison of In Vivo and In Vitro Testing of Sunscreening Formulas. Photochem. Photobiol., 1979. Oxford, v.29.

[6] Charisma, S. L. Daya Tabir Surya dan Antioksidan Formula Krim Ekstrak
Rimpang Kencur (Kaempferia galanga L) dan Rimpang Temu Kunci (Boesenbergia (Roxb.) Schlecht). 2012. Universitas Muhammadiyah Purwokerto.

[7] Estiasih T and Ahmadi. Teknologi Pengolahan Pangan, Edisi 1 Cetakan 2. 2011. Bumi Aksara. Jakarta .

[8] Sulistianingrum, F dan Maspiyah. Pengaruh Perbedaan Presentase Tepung Biji Buah Pinang Terhadap Kualitas Sediaan Masker Kulit Wajah Berbahan Dasar Tepung Beras Sebagai Kosmetika Tradisional. 2014. Fakultas Teknik Universitas Negeri Surabaya. Surabaya

[9] Cameron, D.K and Wang, Ya-Jane. Application of Protease and HighIntensity Ultrasound in Corn Starch Isolation from Degermed Corn Flour.[Jurnal]Journal Food Sience University Of Arkansas : 2006. Volume 83, Number 5. Page 505-509

[10] Prasiddha, IJ et-al. 2016. Potensi Senyawa Bioaktif Rambut Jagung (Zea mays L.) untuk Tabir Surya Alam. (Jurnal). Universitas Brawijaya Malang. Malang.

[11] Maisuthisakul P., M. Suttajit, and R. Pongsawatmanit. Assessment of phenolic content and free radicalscavenging capacity of some Thai indigenous plants. Food Chenistry. 2007; 100 (4) : 1409 - 1418

[12] Wood, C. \& Murphy, E. Sunscreens Efficacy. Glob. Cosmet. Ind. Duluth, 2002; v.167:38-44.

[13] Sugihartini N, Optimization composition of Rice Fluor and Ethanol Fraction of Plantago major, L Leaf in Formulation of Sunscreen by Simplex Lattice Design Method. Jurnal Ilmiah Kefarmasian, 2011; $1(2),: 63-70$

[14] Agustin R, dkk. Formulasi Krim Tabir Surya dari Kombinasi Etil p-Metoksisinamat dengan Katekin. 2013; Fakultas Farmasi Universitas Andalas. 
[15] Saewan N and Jimtaisong A. Photoprotection of Natural Flavonoids. Journal of Applied Pharmaceutical Science 2013 ; 3 (9): $129-141$. 